\title{
A escuta opositora de canções brasileiras: Negociando sentidos entre performances e versões
}

\author{
The oppositional listening regarding Brazilian songs:
} Negotiating meanings between performances and versions

\section{Lucianna Furtado}

Doutoranda do Programa de Pós-Graduação em Comunicação Social da Universidade Federal de Minas Gerais (PPGCOM-UFMG) e mestre pela mesma instituição. Integrante do Coragem - Grupo de Pesquisa em Comunicação, Raça e Gênero; e do Escutas - Grupo de Pesquisa e Estudos em Sonoridades, Comunicação, Textualidades e Sociabilidade. Bolsista da Coordenação de Aperfeiçoamento de Pessoal de Nível Superior (Capes).

\section{Laura Guimarães Corrêa}

Professora Doutora do Programa de Pós-Graduação em Comunicação Social da UFMG, com vínculo à linha Processos Comunicativos e Práticas Sociais. Integra a diretoria do Centro Internacional de Semiótica e Comunicação (CISECO) e coordena o Grupo de Pesquisa em Comunicação, Raça e Gênero (Coragem).

\section{Submetido em 22 de Março de 2020} Aceito em 29 de Maio de 2020

\section{RESUIMO}

A partir do conceito de olhar opositor de bell hooks e de leitura negociada em Stuart Hall, este artigo reflete sobre versões de canções brasileiras (ligadas ao samba, especialmente) em que as ouvintes e intérpretes subvertem sentidos ao contestar discursos, masculinos em sua maioria, marcados pelo sexismo, pela heteronormatividade, pelo racismo e pelo classismo, entre outras formas de opressão, presentes na música popular. Compreendendo o samba como forma afro-brasileira marcada por histórias de resistência, as versões contestadoras que destacamos não pretendem anular a versão de base, mas propõem uma negociação - política, musical com os sentidos dominantes ou preferenciais.

PALAVRAS-CHAVE: Racismo; Sexismo; Interseccionalidade; Versões musicais; Samba.

Dossiê A Música e suas Determinações Materiais - https://revistaecopos.eco.ufri.br/ 


\section{ABSTRACT}

Grounded on the concepts of oppositional gaze, by bell hooks, and negotiated code,by Stuart Hall, this paper reflects about versions of Brazilian songs in which the listeners orperformers subvert meanings through contesting discourses, mostly male, that are tainted bysexism, heteronormativity, racism, classism, among other forms of oppression, present inpopular music; discussing, especially, samba. Understanding samba as an Afro-Braziliangenre characterized by histories of resistance, the contesting versions that we discuss do notintend to nullify the base version, but instead propose a negotiation - a political, musicalnegotiation - with the dominating or preferential meanings.

KEYWORDS: Racism; Sexism; Intersectionality; Musical versions; Samba.

\section{INTRODUÇÃO}

Por sua capacidade de afetação e pela abrangência de sua presença na vida cotidiana, a música popular talvez seja a forma artística com o maior condão de compartilhar ideias e de construir pontes e pontos de interação com seus públicos. Assim como outros produtos midiáticos e culturais, as canções do rádio, das ruas, da televisão, dos shows, nos dizem quem somos e onde estamos na sociedade. Podemos dizer que a música é formadora de subjetividades, construtora de sujeitos. Como admiradoras e consumidoras de música, nossa subjetividade foi e tem sido constituída por expressões como "não deixe o samba morrer", "gente é pra brilhar, não pra morrer de fome", "respeite meus cabelos, brancos" e, mais recentemente, "fogo nos racista", para citar algumas. Essa construção subjetiva acontece em relação ao outro - e é sabido que as relações em sociedade são perpassadas por estruturas de poder.

Assim, fomos confrontadas também, desde cedo, nas canções, com frases e expressões como "uma mulher não deve vacilar", "ele é o homem, eu sou apenas uma mulher", "nega do cabelo duro" e outras ainda menos lisonjeiras. Por isso, chama a nossa atenção a prática da escuta opositora e da (re)criação de canções em versões que mostram, ao mesmo tempo, a contestação e a negociação discursiva com ideias preconceituosas, desumanizantes e objetificadoras sobre grupos sociais vulnerabilizados. A escuta opositora das cantoras que aqui vamos citar tensiona e questiona a versão de base na medida em que é uma reação contra a opressão cantada e, 
ao mesmo tempo, uma tentativa de se manter o prazer de ouvir e performar uma canção (seja pelo seu valor musical, cultural, histórico) sem que sua letra possa, impunemente, agredir e reafirmar valores sexistas.

Este artigo trata primeiramente, com López Cano (2011), do potencial teórico e intelectual da versão enquanto forma metatextual em relação à canção de base. Em seguida, apresentamos e nos apropriamos do conceito de olhar opositor em bell hooks (2019) para defender a validade, a potência e a aplicabilidade do conceito de escuta opositora. Trazemos, ainda nessa seção, a discussão sobre as posições hipotéticas de leitura propostas por Stuart Hall (2003), argumentando que a prática de criação de versões (seja por meio de performances ou de alterações nas letras das canções) é uma espécie de leitura negociada, que não aniquila a obra nem o compositor, mas acrescenta camadas de sentido sobre ela, atualizando e trazendo uma nova/outra voz - em sentido literal e político - àquela composição. Em seguida, apresentamos exemplos em que a escuta opositora e a prática negociada se concretizam em versões e performances, destacando, na análise, o trabalho da cantora Teresa Cristina, que recria, de forma crítica, versões de referência dos sambas de Cartola e Noel Rosa.

\section{A versão musical como transformação crítica e construção teórica}

Segundo Rubén López Cano (2011), uma versão é uma atualização, em nova gravação ou performance, de uma canção já interpretada ou gravada anteriormente, tomando-a como uma experiência de escuta que se abre para um ato criativo sobre o espectro de significação. 0 autor tensiona o costume de nomear a canção de base como “original”, destacando que a percepção da originalidade passa pela memória popular, contextos dos públicos, alcance e circulação - de modo que, mesmo que uma versão não seja a primeira, pode ser lembrada como tal. Assim, o autor prefere os termos: canção de base; versão hegemônica ou dominante; versão de referência.

Em sua visão, a versão atualizada pode se relacionar com a de referência de muitas formas, desde se manter o mais parecida possível, passando por mudanças em 
maior ou menor medida, até modificar sua estrutura a ponto de se tornar uma música independente. Na modalidade que transforma a significação, o autor destaca:

Embora grande parte da estrutura e letra da canção seja respeitada, o arranjo, a transformação de gênero ou estilo e a performance introduzem um distanciamento da versão de referência que se traduz em um comentário ou interpretação, uma oposição ou contradição com o significado ou estética do original, uma revisão crítica de seu significado, a revelação de uma verdade que não conhecíamos a respeito da versão de referência ou uma distanciação irônica que desconstrói os pilares semióticos do tema (LÓPEZ CANO, 2011, p. 65-66, tradução nossa, grifo nosso).

Para o autor, essa modalidade introduz olhares críticos, reflexivos ou desconstrutivos em um vínculo metatextual com a versão de referência, se assemelhando às versões satíricas ou paródicas; estas, porém, tendem ao deboche em relação ao cantor ou à canção. López Cano lista outras estratégias, mas, neste artigo, pretendemos focar nas já descritas, explorando o potencial da versão para operar como crítica, reinterpretação ou análise da canção de base. Em sua concepção, como essas obras (as versões atualizadas) tratam de outras (as de base), aquelas se caracterizam como intelectuais ou teóricas em relação a estas últimas. Segundo o autor, esse vínculo metatextual subordina as versões atualizadas às de referência não por razões ontológicas, mas epistemológicas, já que promovem uma construção teórica sobre estas.

$\mathrm{Na}$ próxima seção, discutiremos como as práticas de escuta podem motivar criações e versões a partir de oposições ligadas aos eixos de poder, opressão e violência, isto é, aos marcadores de raça, gênero, classe, sexualidade, dentre outros.

\section{Práticas opositoras: do olhar à escuta}

Em seu ensaio "O olhar opositor: mulheres negras espectadoras", a intelectual negra bell hooks (2019) parte de experiências cotidianas em que o olhar pode ser instrumentalizado como movimento de enfrentamento, resistência e desafio à autoridade para conectar estas vivências à historicidade escravagista estadunidense, demonstrando que o poder racializado e as práticas de restrição e punição construíram uma relação traumática sobre os olhares, frequentemente negando às pessoas negras o 
direito de olhar. Também no Brasil, pessoas escravizadas foram castigadas por olhar de frente, tendo sido forçadas a olhar para o chão.

Embora enfatize o poder da autoridade nessas relações, hooks negrita que também emergem formas de resistência, evidenciando que as restrições sobre os olhares negros resultaram em um intenso desejo de olhar, de encarar corajosamente e mudar a realidade por meio desse olhar - um olhar opositor. Politizando as relações do olhar, hooks destaca a agência das pessoas negras e nossa capacidade de interrogar o olhar do Outro que nos observa, bem como de devolver o olhar, de olhar para nós mesmas e nomear o que vemos.

Na visão de hooks, o olhar opositor permeia as relações das pessoas negras com a televisão e o cinema mainstream - enfatizando sua posição não como consumidoras passivas ou facilmente manipuláveis, mas como sujeitos conscientes das noções racistas ali reproduzidas e perpetuadas. A autora afirma que essas produções culturais eram, para ela, uma forma de contato com o mundo branco e de desenvolver olhares de espectatorialidade crítica, destacando que as pessoas negras as contestavam e interrogavam, recusando a identificação com os estereótipos representados nessas obras.

Hipoteticamente, qualquer espectador pode desempenhar uma postura crítica diante de construções racistas e sexistas, dentre outras formas de opressão. No entanto, para os sujeitos subalternizados, o encontro audiovisual ganha contornos de uma negação do próprio self e do próprio lugar na sociedade, uma violência contra a própria subjetividade individual e coletiva. Os sujeitos de grupos politicamente privilegiados podem - e devem/deveriam - se opor a essas formas de representação por um imperativo ético, mas não são vitimados por elas. Ao contrário, são beneficiados, na medida em que sua superioridade é construída, reafirmada e cristalizada por meio da elaboração e naturalização da inferioridade do outro. É precisamente nessa assimetria que reside a importância de centralizar os olhares e vozes opositores dos sujeitos subalternizados em relação à produção midiática, cultural e intelectual.

Nesse contexto, hooks evidencia uma diferenciação de gênero nos olhares negros: a ficção permitia aos homens negros uma participação imaginária na política 
falocêntrica do olhar sobre as mulheres brancas - o que era violentamente negado em suas interações sociais -, enquanto os olhares das mulheres negras são atravessados pela opressão entrecruzada de raça e gênero. A autora descreve diferentes reações das espectadoras negras diante das representações convencionais, desde a completa rejeição até a cumplicidade e subordinação, como formas de estabelecer uma experiência prazerosa com o cinema.

Com a maioria das entrevistadas, hooks identificou uma postura ativa de contestação e recusa à identificação - evidenciando o olhar opositor não como um atributo essencialista das mulheres negras, mas como um gesto desenvolvido a partir de experiências dolorosas e de subjetividades empenhadas em resistir às formas dominantes de olhar e conhecer. Para a autora, o prazer visual das espectadoras negras críticas reside precisamente no prazer de interrogar. Como ferramenta analítica, o olhar opositor permite abordar as tradicionais posições de sujeito-objeto das relações do olhar e a insuficiência das análises que não consideram o entrecruzamento de marcadores da desigualdade. Nesse sentido, consideramos que o olhar opositor se estende para além do cinema e televisão, permeando as relações epistêmicas como um todo e auxiliando a refletir sobre as práticas de consumo cultural de outros formatos como, por exemplo, a música.

Assim como a resistência contra as violências de representação desenvolvem uma espectatorialidade opositora, as contribuições de hooks podem ser adaptadas para refletir sobre práticas de escuta opositora, permeadas por subjetividades e posicionamentos de resistência às formas dominantes de ouvir e conhecer. Esse movimento complexifica as relações de escuta musical para além dos polos de aceitação passiva ou recusa total, aproximando-se da posição que Stuart Hall (2003) chamou de código negociado.

Para o autor, o ponto de vista hegemônico/preferencial é aquele que define dentro de seus termos o horizonte mental, o universo de significados e relações possíveis em uma sociedade ou cultura. É também aquele que carrega consigo o selo da legitimidade, pois parece coincidir com o que é "natural", "inevitável" ou "óbvio" a respeito da ordem social em dado tempo e espaço (HALL, 2003, p. 401). 0 autor acredita 
que em toda sociedade existem sentidos dominantes, que organizam domínios discursivos por meio de códigos sociais. Esses sentidos preferenciais são permeados pelas dinâmicas de poder, por meio de práticas discursivas que, muitas vezes, reafirmam desigualdades e opressões.

Hall entende que a leitura - ou escuta, no caso deste artigo - dos produtos midiáticos pode ser classificada de acordo com o grau de concordância ou de adesão aos sentidos preferenciais, uma vez que, no processo comunicacional, "não existe uma necessária correspondência entre codificação e decodificação" (HALL, 2003, p. 399-400). $\mathrm{Na}$ troca discursiva, não há garantia de que aquilo que se diz/escreve/mostra será interpretado como se esperava no momento da codificação. A depender de quem ouve/lê/assiste, há inúmeras articulações possíveis para a combinação entre a codificação e a decodificação de produtos da cultura.

Como proposta teórico-metodológica para a análise da recepção do jornalismo televisivo, Hall (2003) identifica três posições hipotéticas de leitura. Na primeira, há concordância com o sentido hegemônico conotado na mídia. Na segunda hipótese, a do código negociado, as definições preferenciais são aceitas, mas a leitora, ouvinte ou espectadora ${ }^{1}$ cria suas próprias regras para decodificar a mensagem, misturando, assim, elementos de adaptação e oposição. No terceiro caso, a leitura é de franca oposição: reconhece o sentido hegemônico, mas discorda totalmente deste. As categorias criadas por Hall são boas para pensar a apreensão, a escuta e a recriação de canções consagradas da música popular.

A escuta crítica e as versões criadas a partir dela permitem pensar como as relações afetivas com as canções podem ser entrelaçadas com discordâncias, contrapontos e dissonâncias. A transposição das contribuições de hooks sobre as relações do olhar para as práticas de escuta opositora, que propomos aqui, possibilita discutir como o prazer da escuta musical pode ser atravessado e, principalmente, enriquecido pelo ato de interrogar criticamente.

Nesse contexto, a apreciação cultural opositora demanda algum contraponto, que pode se materializar na reflexão crítica, em protestos e intervenções e na criação autoral

\footnotetext{
${ }^{1}$ Entendendo que a linguagem é política, optamos por não adotar a forma gramaticalmente correta do masculino universal em todo o artigo. Por vezes, utilizaremos também o feminino para nos referirmos a homens e mulheres.
}

Dossiê A Música e suas Determinações Materiais - https://revistaecopos.eco.ufri.br/ 
de outras produções e performances que se posicionem criticamente. Essas práticas opositoras, ao demarcar relações de poder e nomear opressões, antecedem e fundamentam transformações sobre os modos de pensar e fazer cultura, sobre as formas de existir e interagir em sociedade. Na próxima seção, discutiremos exemplos que permitem vislumbrar como as experiências de escuta opositora emergem nas criações, intervenções e transformações na música.

\section{Ecos da escuta opositora}

As práticas de escuta opositora, mesmo quando emergem individualmente, não se limitam a essa dimensão, mas dialogam com contextos mais amplos de disputas político-culturais. Sendo as relações de poder estruturais e estruturantes, estas perpassam os processos de produção, circulação, escuta e crítica em todos os gêneros musicais - embora alguns possam se destacar mais nas tendências a gestos de opressão e/ou resistência em determinados eixos de poder, bem como desenvolver modos específicos de manifestar opressão e/ou resistência, característicos do repertório cultural de cada gênero. Discutiremos alguns casos que mobilizaram a atenção dos públicos e de jornais, revistas e portais de notícias on-line nos últimos anos.

Um exemplo é a manifestação de Sandy \& Junior: a canção "Maria Chiquinha”, que trata do feminicídio de forma acrítica e banalizada por meio do humor, não entrou na setlist do show de 30 anos de carreira. Quando a plateia cantou-a durante um intervalo, Junior Lima afirmou que essa canção dos anos 90 já não é aceitável atualmente. Na esteira do caso, uma coluna d'O Globo listou trechos de músicas que naturalizam o sexismo e a violência contra as mulheres: "Se te agarro com outro, te mato / Te mando algumas flores e depois escapo" (Sidney Magal); "To a fim de você / E se não tiver, cê vai ter que ficar / Vai namorar comigo sim (...) Se reclamar, cê vai casar também" (Henrique e Juliano); "Só surubinha de leve com essas filha da puta / Taca bebida / Depois taca a pica e abandona na rua" (MC Diguinho), dentre outras².

\footnotetext{
2 "14 músicas que trazem em seus versos machismo ou violência contra a mulher". O Globo, 22 jul. 2019. Disponível em glo.bo/36dYSz3. Acesso em 22 jan. 2020.
}

Dossiê A Música e suas Determinações Materiais - $\underline{\text { https://revistaecopos.eco.ufri.br/ }}$

ISSN 2175-8689-v. 23, n. 1, 2020

DOI: 10.29146/eco-pos.v23i1.27477 
Um texto semelhante, da Rolling Stone, lista canções que naturalizam diversas formas de sexismo, como a importunação sexual ("Esporrei na Manivela”, Raimundos); abuso infantil ("Me Lambe", Raimundos); violência doméstica e feminicídio ("Run for your life", Beatles; "Faixa Amarela", Zeca Pagodinho); entrecruzamentos com outros eixos de poder, como a fetichização no contexto da lesbofobia ("0 rock das aranha", Raul Seixas); a romantização do abuso de mulheres escravizadas em uma manifestação de misogynoir ${ }^{3}$ ("Mulata assanhada", Ataulfo Alves), dentre outros exemplos ${ }^{4}$.

A ênfase em mostrar que práticas sexistas perpassam todos os gêneros musicais se deve à tendência racista e elitista de atribuí-las apenas, ou desproporcionalmente, ao funk e ao rap. Em declaração à Folha de Pernambuco, a cantora Karina Buhr identifica que as culturas musicais da periferia são sempre os primeiros alvos desse questionamento, enquanto manifestações de cantores como Vinicius de Moraes ("As muito feias que me perdoem, mas beleza é fundamental", na poesia "Receita de Mulher") e Noel Rosa (na canção "Mulher Indigesta”) costumam passar despercebidas 5 .

Em resposta à seletividade das críticas, um grupo de publicitárias criou, em 2018, o site Música Machista Popular Brasileira (MMPB). Em declaração ao jornal O Tempo, Lilian Oliveira, uma de suas idealizadoras, comenta que o projeto partiu da repercussão negativa de "Surubinha de Leve", de MC Diguinho: "Na época (do lançamento), muitas pessoas demonizaram o funk, como se o machismo fosse exclusivo desse ritmo. Então, para quebrar esse argumento cego e elitista, criamos o site"6. Para além do contexto brasileiro, um texto do Nexo evidencia o sexismo, xenofobia e racismo no heavy metal, bem como uma tendência do folk metal a enaltecer valores culturais hegemonicamente brancos, masculinos, individualistas, nacionalistas e neoliberais ${ }^{7}$.

\footnotetext{
3 Segundo Moya Bailey e Trudy (2018), o termo misogynoir caracteriza formas racializadas de sexismo especificamente destinadas contra mulheres negras, demarcando o entrecruzamento destes eixos de opressão na violência física e simbólica.

4 "Politicamente incorreto: 14 músicas antigas que nunca seriam lançadas hoje". Rolling Stone, 23 jun. 2019. Disponível em bit.ly/2v8MXFD. Acesso em 22 jan. 2020.

5 "Cultura do machismo está em todos gêneros musicais". Folha de Pernambuco, 4 fev. 2018. Disponível em bit.ly/2GgCIRX. Acesso em 22 jan. 2020.

6 "Passam-se os anos, permanece o machismo na música brasileira". O Tempo, 15 abr. 2018. Disponível em bit.ly/3605lHO. Acesso em 22 jan. 2020.

7 "A cena heavy metal decidiu debater racismo e machismo. Aqui estão os motivos". Nexo Jornal, 31 maio 2016. Disponível em bit.ly/38wPgRy. Acesso em 22 jan. 2020.
}

Dossiê A Música e suas Determinações Materiais - https://revistaecopos.eco.ufri.br/ 
Paralelamente, todos os gêneros musicais podem apresentar contranarrativas de resistência, configurando disputas de representação e valores culturais. Outro texto d'O Globo listou canções que denunciam o sexismo e a violência contra a mulher: "Maria da Vila Matilde”, de Elza Soares; “100\% Feminista”, de MC Carol e Karol Conká; "Não é não”, de Lila; “Dizputa”, de Carol Naine, dentre outras ${ }^{8}$ - contemplando composições próprias e interpretações de letras progressistas compostas por outros músicos. Mesmo as cantoras do feminejo, que rejeitam o título de feministas e reproduzem, em suas canções, valores sexistas e ofensas misóginas direcionadas a outras mulheres, têm, simultaneamente, contestado outros estereótipos e preconcepções machistas em suas canções - contribuindo, de alguma forma, para popularizar essas ideias entre grupos avessos a pautas progressistas ${ }^{9}$.

Na visualidade, hooks (2019) destaca que os olhares opositores de espectadores desenvolveram o cinema negro independente, respondendo às relações normativas do olhar com contrapropostas para a construção política e visual da negritude. Desse modo, as composições dessas mulheres, com teor feminista e antirracista, se enquadram como desdobramentos da escuta opositora, apresentando contrapropostas para as relações entre sujeito e objeto que constituem a indústria musical e a vida social. Neste artigo, nos interessa aprofundar em outra forma de aparição, referente a canções específicas, para identificar como as práticas de escuta opositora reconfiguram as relações das ouvintes com essas composições e reverberam em versões que as transformam.

Nos últimos anos, os Racionais MC's têm se retratado por "Mulheres Vulgares", lançada em 1993. Removida do repertório, a canção trazia versos como "É uma cretina que se mostra nua como objeto / É uma inútil que ganha dinheiro fazendo sexo / No quarto, motel, ou tela de cinema / Ela é mais uma figura vil, obscena". Em meio a questionamentos e mudanças culturais, Mano Brown se pronunciou sobre o machismo descarado da letra e afirma ter mudado sua música, comportamento e entendimento do

\footnotetext{
8 "Seis músicas brasileiras que denunciam em suas letras a violência contra a mulher". O Globo, 23 jul. 2019. Disponível em glo.bo/2NQ3nct. Acesso em 22 jan. 2020.

9 "Você tem um minuto para ouvir a palavra do feminejo?". The Intercept Brasil, 28 dez. 2018. Disponível em bit.ly/2Ggxkys. Acesso em 22 jan. 2020.
}

Dossiê A Música e suas Determinações Materiais - https://revistaecopos.eco.ufri.br/ 
mundo ${ }^{10}$. Em entrevista ao jornal $O$ Tempo, Edi Rock, um dos compositores da faixa, comenta que hoje já não faria uma música como essa, mas destaca que ela marcou uma época: "mostra como eu pensava antigamente e como o homem é machista para falar frases como aquelas"11.

O rapper Criolo também fez mudanças em seu repertório, mas com uma estratégia diferente: além de mudar versos nos shows ao vivo, Criolo alterou palavras na regravação de seu primeiro álbum, Ainda Há Tempo (2006/2016). Os versos “Os traveco tão ali, aaah / Alguém vai se iludir”, mudaram para "O universo tá aí” na nova versão de "Vasilhame". Em entrevista à Trip, o rapper atribui a ofensa à própria falta de conhecimento, agradecendo pela oportunidade de se rever e corrigir suas ações. Criolo também alterou "Subirusdoistiozin", do álbum Nó na Orelha (2011): abordado por uma jovem em um show, que pediu para mudar o verso "as vadias quer mas nunca vão subir", o rapper dialogou com líderes feministas e trocou "vadia" por "vazia", para designar pessoas vazias que não têm algo positivo no coração ${ }^{12}$.

A decisão de Criolo pode parecer um gesto pequeno, por se tratar de uma palavra em cada música. No entanto, ao reescrever esses versos na regravação do álbum e em suas performances, o rapper demonstra consciência da gravidade dessas ofensas, devido ao papel da linguagem cotidiana na legitimação e naturalização de violências sexistas e transfóbicas. Mais do que uma transformação individual, a ação de Criolo revelou abertura aos questionamentos e porosidade frente a mudanças culturais progressistas.

Nesse sentido, as escutas opositoras das ouvintes de "Vasilhame" e "Subirusdoistiozin", além de atravessar suas próprias experiências e complexificar seu prazer musical, impactaram a relação do compositor com sua própria obra. Com a admissão de responsabilidade e as alterações nas letras, a dinâmica interacional da escuta opositora alcança uma nova dimensão: a da escuta atenta do compositor, que não descarta ou deslegitima as críticas, mas se deixa afetar e transformar politicamente pelo gesto opositor de suas ouvintes. As mudanças constituem, assim, um pacto de

\footnotetext{
10 “Mano Brown: 'Não faz sentido o homem ser beneficiado só por ser homem”'. Revista Claudia, 13 abr. 2018. Disponível em bit.ly/2TMEimz. Acesso em 22 jan. 2020.

11 "Racionais MC's chega a BH com turnê que comemora 30 anos de estrada". O Tempo, 13 set. 2019. Disponível em bit.ly/30JbDjM. Acesso em 22 jan. 2020.

12 “Sempre em Tempo". Revista Trip, 16 maio 2016. Disponível em bit.ly/2RFnN9k. Acesso em 22 jan. 2020.
}

Dossiê A Música e suas Determinações Materiais - https://revistaecopos.eco.ufri.br/ 
reciprocidade na escuta e um compromisso de reconfigurar suas ações de maneira orientada pelo respeito e igualdade.

Cabe enfatizar que Criolo e os Racionais MC's são referências no cenário políticocultural brasileiro com suas contranarrativas de emancipação negra e periférica. Esses fenômenos chamam a atenção para a complexidade interseccional dos sistemas de poder, operando em eixos distintos, mas interligados, que se entrecruzam e modificam as dinâmicas sociais de violência e opressão (CRENSHAW, 1991). Nesse sentido, o pertencimento a um ou mais grupos subalternizados (no caso, rappers negros e periféricos) não os exime de responsabilidade por reproduzir violências simbólicas dos demais marcadores de poder (sexismo, heteronormatividade, cisnormatividade, dentre outros) - mas pode, ao contrário, servir como catalisador para criar laços de solidariedade.

Para além da complexificação da experiência musical das ouvintes, da criação autoral feminista e seleção de letras progressistas e do reposicionamento dos compositores sobre suas canções, discutidos até aqui, as práticas de escuta opositora também reverberam na (re)interpretação de músicas sexistas. Nessa dinâmica, não se trata de compor novas canções, mas de estratégias para ressignificar canções de base com versões ou sátiras. Confrontadas com o afeto pelo conjunto de melodias, arranjos, sonoridades, relações pessoais, memórias e sociabilidades atreladas a uma letra ofensiva, as intérpretes têm tomado a palavra cantada para reescrever a continuidade da história de canções sexistas.

Um exemplo é o caso de "Mulheres": composta por Toninho Geraes e conhecida pela voz de Martinho da Vila desde 1995, a obra ganhou contornos feministas na paródia escrita pelas musicistas negras Doralyce Gonzaga e Silvia Duffrayer, divulgada no Dia da Mulher de 2018 ${ }^{13}$. Duffrayer é uma das integrantes do Samba Que Elas Querem (com Giselle Sorriso, Karina Neves, Angélica Marino, Bárbara Fernandes, Cecília Cruz, Mariana Solis e Julia Ribeiro), que gravou e tem apresentado essa versão em seus shows ${ }^{14}$. Na canção de base, o eu-lírico lista mulheres com quem se relacionou, referindo-se a algumas como "carente" ou "meretriz" e desfiando versos como "Mulheres cabeças e

13 Disponível em youtu.be/klnlPtOaqSs. Acesso em 23 jan. 2020.

14 Disponível em youtu.be/B5YJqc-rK-A. Acesso em 23 jan. 2020.

Dossiê A Música e suas Determinações Materiais - https://revistaecopos.eco.ufri.br/ 
desequilibradas / Mulheres confusas, de guerra e de paz / Mas nenhuma delas me fez tão feliz como você me faz" - reescritos, na versão feminista, como "Mulheres cabeça e muito equilibradas / Ninguém tá confusa, não te perguntei nada / São elas por elas, escuta esse samba que eu vou te cantar". Na paródia, as mulheres deixam de ser objeto de posse, a serem "tidas" pelo eu-lírico, para se posicionarem como sujeitas, que se autodefinem, contestam expectativas masculinas e homenageiam Dandara, Elza Soares, Marielle e Chica da Silva.

Em entrevista à Folha de S.Paulo, Mariana Solis, que toca agogô e caixa no Samba Que Elas Querem, destaca que a paródia não é uma denúncia contra o compositor, mas uma proposta de reflexão: "Toninho foi muito carinhoso; é um cara que a gente admira, tocamos várias dele. Mas, por mais que a versão original seja maravilhosa, não dá mais para aceitar a reprodução de certos comportamentos"15. É possível perceber uma dinâmica ambivalente: há afetividade e prazer na relação com esse samba, mas há também desconforto e contestação às práticas sexistas que sua letra romantiza e naturaliza. A crítica e a reconstrução não são desvinculadas da apreciação e admiração pelas obras: pelo contrário, essa relação afetiva é precisamente o que complexifica a escuta opositora e seus desdobramentos.

Nos casos contextualizados no rap, samba e funk, por exemplo, essas relações têm outras camadas, devido à sua relevância histórica como território de resistência; como espaços de construção e circulação das experiências, cultura, política e conhecimento negros. A proposta de tais movimentos não é apagar esses artistas e suas obras da história da música brasileira - com esses gêneros musicais, isto implicaria tornar-se cúmplice do epistemicídio contra as tradições musicais negras e periféricas. Ao contrário, as escutas opositoras estabelecem canais de diálogo, reflexão e escuta mútua para reconstruir as masculinidades e outras relações de poder, possibilitando transformações culturais e políticas que transcendem a música e ecoam para as demais dimensões da vida social.

Há, ainda, outra possibilidade de ressignificação de canções que não passa por alterações nas letras, mas pela inserção da corporeidade feminina no canto, que

15 “Após versão feminista de 'Mulheres', roda de samba feminina prepara disco". Folha de S.Paulo, 4 mar. 2019. Disponível em bit.ly/2RmcdkE. Acesso em 23 jan. 2020.

Dossiê A Música e suas Determinações Materiais - https://revistaecopos.eco.ufri.br/ 
descaracteriza e subverte a heteronormatividade estabelecida. Referindo-se à performance de modo mais amplo, não especificamente à musical, Diana Taylor (2012) argumenta que os atos da performance articulam saberes sociais e operam conforme sistemas de códigos, convenções e contextos, destacando o potencial das práticas corporais como formas de intervenção, desafio e contestação ao poder. Para a autora, a performance permite recontextualizar, ressignificar, reagir e parodiar como ato estético e gesto de intervenção política, produzindo e reconstruindo conhecimento através do corpo, da ação e do comportamento social.

Um exemplo é a versão de Marina Lima, declaradamente bissexual, de "Mesmo que seja eu" (1984). Composta por Roberto Carlos e Erasmo Carlos, a letra conta com os versos "Você precisa de um homem pra chamar de seu / Mesmo que este homem seja eu". Em entrevista ao Lado Bi, a cantora fala de sua versão como uma dica de libertação: "Eu achei interessante pegar essa música, porque quando o Erasmo cantava, parecia uma coisa meio machista, mas uma mulher cantando, subverteria tudo isso (...), a mesma música, o fato de eu cantar mudaria tudo"16. Em sua versão, a cantora manteve a letra inalterada, revestindo os versos acima citados de uma camada de ironia com sua voz feminina, como um convite a desafiar a heteronormatividade.

Outro caso é a canção "Eu gosto de mulher", composta por Roger Moreira, do Ultraje a Rigor. Quando cantada por Ana Carolina, que se declara publicamente como bissexual e estrelou sua histórica capa na Veja em 2005 ("Sou bi. E daí?"), a canção se transforma, deixando de ser um expoente da fragilidade masculina heteronormativa para emergir como uma afirmação da sexualidade de mulheres lésbicas e bissexuais. Em uma versão ao vivo, a cantora combina estratégias distintas de ressignificação, mudando um trecho que objetifica o corpo feminino - "Você sabe que eu adoro um peito" para "Ninguém sabe o que ela tem no peito" - e dispensando o verso em que o eu-lírico se afirma "meio atrasadão, conservador, reacionário e caretão"17. Paralelamente, a letra inalterada do refrão, “Ooo ooo ooo / Eu gosto é de mulher!”, associada à sua voz e

\footnotetext{
16 “Marina Lima: 'posei pra Playboy por recomendação médica'”. Lado Bi - TV UOL, 21 jan. 2016. Disponível em bit.ly/2t00j4G. Acesso em 27 jan. 2020.

17 Disponível em youtu.be/18LXw1M3iDM. Acesso em 27 jan. 2020.
}

Dossiê A Música e suas Determinações Materiais - https://revistaecopos.eco.ufri.br/

ISSN 2175-8689 - v. 23, n. 1, 2020

DOI: 10.29146/eco-pos.v23i1.27477 
corporeidade femininas, promove um contraponto ainda mais contundente a esses modos de masculinidade e heteronormatividade.

Ressaltamos ser comum que intérpretes mantenham o gênero do eu-lírico das composições; no entanto, quando essas letras são abertamente sexistas e heteronormativas, sua interpretação por mulheres lésbicas ou bissexuais atribui à performance musical uma dimensão permeada, transformada e enriquecida pela corporeidade feminina e por sua sexualidade não-normativa, em uma potência que também se aplica às corporeidades trans e não-binárias. Nessa versão, a troca de gênero musical também opera uma função referente às convenções de gênero no contexto sexual, jogando com imaginários culturais: enquanto o rock é visto como um gênero musical dominado pela presença masculina e por valores ligados à masculinidade hegemônica, um número considerável de mulheres da MPB são declaradamente lésbicas ou bissexuais.

$\mathrm{Na}$ próxima seção, discutiremos práticas de escuta opositora e suas reverberações na performance a partir do trabalho da cantora Teresa Cristina. Abordaremos suas estratégias e recursos para contestar, confrontar ou contornar aspectos problemáticos das composições de Cartola e Noel Rosa, sambistas consagrados cujas canções fazem parte de seu repertório.

\section{Temos e teremos, sim, outros grandes sambas}

A cantora carioca Teresa Cristina iniciou sua carreira artística nos anos 90, com projetos musicais diversos antes de cantar no Bar Semente com o grupo homônimo, na Lapa, a partir do final da década. Além de canções autorais, seu repertório trazia Paulinho da Viola e Candeia como principais referências. Após cinco anos com o grupo Semente, Teresa Cristina iniciou um projeto de homenagens a grandes sambistas, com tributos a Cartola e Noel Rosa.

Em uma entrevista em dueto ao O Globo, Teresa Cristina e Caetano Veloso discutem as contradições de Noel e seus desconfortos com determinadas músicas. Na concepção de Caetano, há um lado racista e classista em Noel Rosa, cuja obra marcou a 
entrada da classe média no samba, apontando a documentação desse fato histórico em "Feitiço da Vila" e outras canções. No diálogo, Teresa Cristina explica que, por isto, essa música não faz parte de seu repertório ${ }^{18}$. Em entrevista ao UOL, ela comenta que já se aborreceu muito e chegou a perder amizades em discussões sobre "Feitiço da Vila", e se deu o direito de não cantá-la ${ }^{19}$.

A canção, que apresenta Vila Isabel como um lugar onde "quem é bacharel não tem medo de bamba", expressa com naturalidade seu próprio racismo religioso e epistêmico: "A vila tem um feitiço sem farofa / Sem vela e sem vintém / Que nos faz bem / Tendo nome de princesa / Transformou o samba / Num feitiço decente / Que prende a gente". As contribuições de Rodney William (2019) sobre apropriação cultural permitem compreender os processos racistas e elitistas que buscam "purificar" ou "aprimorar" o samba por meio do apagamento dos elementos culturais mais explicitamente associados à negritude e da ruptura com os sujeitos negros que a construíram.

William (2019) elucida a apropriação cultural como uma violência no contexto do racismo e do colonialismo, que consiste em desapropriar elementos de resistência cultural e estética de um grupo subalternizado, desvirtuando seu sentido simbólico e político. 0 autor destaca que esse processo se ancora na marginalização negra e no esvaziamento de significados históricos: a ausência de contrapartida ou retorno financeiro da indústria musical para muitos sambistas negros e periféricos; o preconceito, violência e perseguição policial sistemática contra esses sujeitos; a desconexão com a resistência negra para manter vivas as práticas culturais e religiosas. Desse modo, William afirma que pessoas brancas podem, sim, cantar samba - o que não podem, eticamente, é negar sua origem, desvinculando-o do povo negro que o criou e desconsiderar que é uma das expressões mais originais da cultura negra.

"Mulher Indigesta" é outra canção de Noel que Teresa Cristina manteve fora do repertório. Com os versos "Mas que mulher indigesta, indigesta / Merece um tijolo na testa / E quando se manifesta / O que merece é entrar no açoite", cantados com humor e

18 "Caetano e Teresa Cristina conversam sobre as contradições de Noel Rosa”. O Globo, 9 mar. 2018. Disponível em glo.bo/37qmFwO. Acesso em 24 jan. 2020.

19 “Teresa Cristina canta Noel Rosa para Temer: 'O Brasil dos anos 30 ainda existe'”. Entretenimento UOL, 11 maio 2018. Disponível em bit.ly/3aP88gy. Acesso em 24 jan. 2020.

Dossiê A Música e suas Determinações Materiais - https://revistaecopos.eco.ufri.br/ 
desembaraço, a música banaliza esses gestos de violência contra a mulher. Na entrevista ao UOL mencionada anteriormente, Teresa Cristina afirma que não se deve "passar pano" para letras ofensivas, e destaca não se tratar apenas de Noel, mas de vários outros sambas que ela deixou de cantar. A cantora identifica, por outro lado, um acerto do compositor em "X do Problema", narrada em primeira pessoa por uma mulher que se afirma independente e diplomada na escola de samba. Na entrevista com Caetano, citada acima, Teresa diz que essa e outras canções progressistas de Noel acabam por redimir sua obra.

Pelas declarações de Teresa Cristina, que sempre se manifesta contra o racismo e o sexismo dentro e fora do samba, é possível perceber que suas discordâncias com os compositores emergem entrelaçadas com a admiração e o respeito pelo conjunto de suas obras - o que explica sua escolha por homenageá-los, sim, mas com ressalvas. Em entrevista ao El País ${ }^{20}$, a cantora defende que não se trata de demonizar esses sambas, mas de criar outros, que representem melhor as mulheres.

Na mesma entrevista, Teresa Cristina evidencia esse critério na homenagem a Cartola, preferindo não cantar "Feriado na Roça". Embora o considere "um samba rural lindo", de melodia maravilhosa, a cantora lembra que o eu-lírico, decepcionado por sua amada retornar à roça de braços dados com outro homem, confessa dar dois tiros no casal. Com a tradicional melancolia de Cartola, termina com os desesperadores versos: "E me encontraram com uma arma fumegando / Seu doutor, rindo e chorando / Se morreram os dois, não sei". Embora prefira não reiterar a mensagem, a cantora não lança a culpa sobre Cartola de modo individual: ela destaca não ser um caso isolado e tampouco ser exclusividade de sua época, sendo comum, ainda hoje, um homem não aceitar a separação e matar a ex-companheira. Nessa toada, Teresa Cristina enfatiza a relação com mudanças culturais mais amplas, defendendo o apoio a vítimas de assédio, sexismo e violência.

Outra canção apontada como fonte de incômodo foi "Tive sim" - que, no entanto, entrou para o repertório, em versões em que a cantora não se esquivou da discordância: ao contrário, preferiu concretizar esse conflito em sua performance e canto. Para

20 “Teresa Cristina: 'O samba reflete o machismo, mas de um modo menos hipócrita”'. El País, 25 abr. 2017. Disponível em bit.ly/2tXSsXN. Acesso em 31 jan. 2020.

Dossiê A Música e suas Determinações Materiais - https://revistaecopos.eco.ufri.br/

ISSN 2175-8689 - v. 23, n. 1, 2020

DOI: 10.29146/eco-pos.v23i1.27477 
discutirmos essa abordagem e suas nuances, cabe lembrar a letra da versão de referência, composta por Cartola:

Tive, sim

Outro grande amor antes do teu

Tive, sim

O que ela sonhava eram os meus sonhos e assim

Íamos vivendo em paz

Nosso lar, em nosso lar sempre houve alegria

Eu vivia tão contente

Como contente ao teu lado estou

Tive, sim

Mas comparar com o teu amor seria o fim

Evou calar

Pois não pretendo, amor, te magoar

Aiai, aiai

Pois não pretendo, amor, te magoar

Esta canção pode ser diferenciada de "Feriado na Roça" (Cartola) e "Mulher Indigesta" (Noel Rosa) em função da forma de sexismo que cantam: enquanto estas narram, respectivamente, um feminicídio e uma argumentação pela hostilidade e agressão física, "Tive Sim" traz uma forma relativamente mais sutil, que não agride fisicamente, mas opera por meio da crueldade emocional no relacionamento afetivosexual. A comparação entre a companheira atual e a anterior parece seguir critérios de submissão feminina: "O que ela sonhava eram os meus sonhos e assim / Íamos vivendo em paz", sugerindo que a individualidade e os sonhos próprios da mulher perturbam essa paz. Ao romantizar o quanto era contente com o "grande amor antes do teu", o eulírico deixa explícito que o relacionamento atual é insuficiente e opaco frente ao anterior - que era melhor, pois "comparar com o teu amor seria o fim". Na letra, ele ainda pondera que prefere calar, pois não pretende magoar a atual. Ora, ele não calou, já disse 
e, provavelmente, já magoou a mulher com a revelação. Teresa Cristina aponta para a crueldade dessa comparação e, fazendo um exercício reverso, observa que o contrário seria inimaginável: uma mulher dizendo ao companheiro atual que a sua relação com outro homem era mais satisfatória.

Vamos discutir dois momentos de "Tive Sim" produzidos pela cantora: uma versão $^{21}$ gravada em 2015 para o CD/DVD Teresa Cristina Canta Cartola (2016), ao lado do violonista Carlinhos Sete Cordas; e sua mudança de estratégia para lidar com o sexismo expresso nessa canção, conforme narrada pela cantora na entrevista de 2017 ao El País, citada acima, e posta em prática em suas apresentações. No primeiro momento, a cantora não modifica a letra, mas é possível perceber recursos expressivos vocais, faciais e corporais que reconfiguram a canção, materializando o conflito e a oposição na performance.

Na versão do primeiro momento, Teresa Cristina incorpora algumas expressões emocionais do eu-lírico - como no verso "E eu vivia tão contente", em que encena o prazer da lembrança (frames 1 e 2). Em seguida, parece acordar daquela memória para se redimir da fala junto à companheira, "Como contente ao teu lado estou" (frames 3 e 4). Ao final da primeira execução da letra, é possível ouvir, em sua voz, a presença de um riso discreto que introduz notas de um leve deboche, acrescentando outra camada de sentido ao "Aiai, aiai" (frames 5 e 6) - que se associa de forma sarcástica à fala anterior, de que não pretendia magoar a companheira.
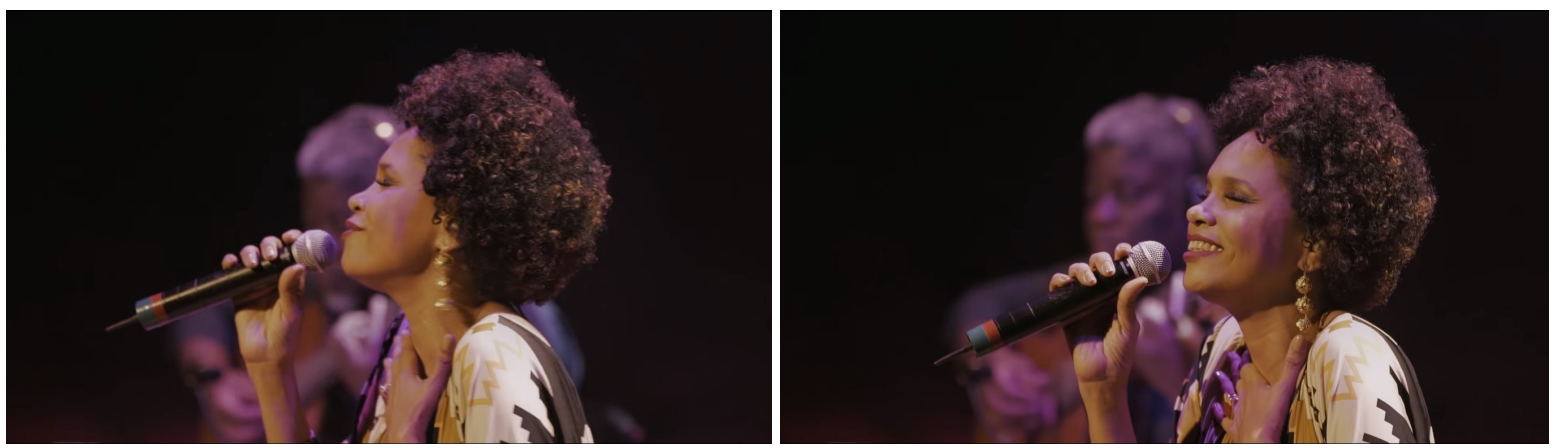

Frames 1 e 2. Fonte: YouTube.

21 Versão publicada no canal de Teresa Cristina no YouTube. Disponível em youtu.be/hYYCV2rXe9E. Acesso em 31 jan. 2020.

Dossiê A Música e suas Determinações Materiais - https://revistaecopos.eco.ufrj.br/

ISSN 2175-8689 - v. 23, n. 1, 2020

DOI: 10.29146/eco-pos.v23i1.27477 

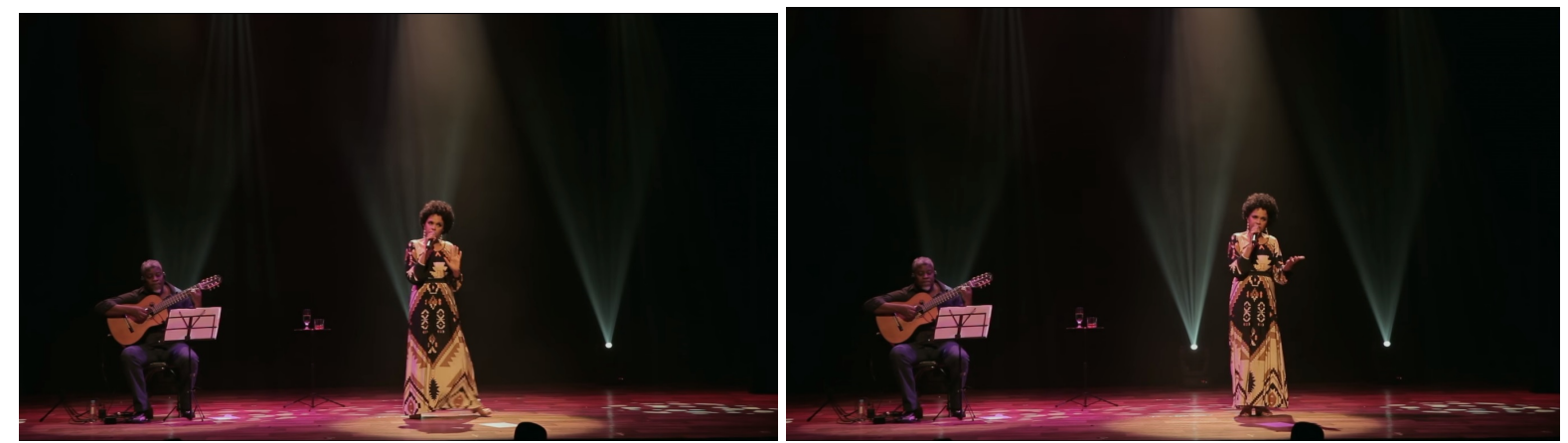

Frames 3 e 4. Fonte: YouTube.
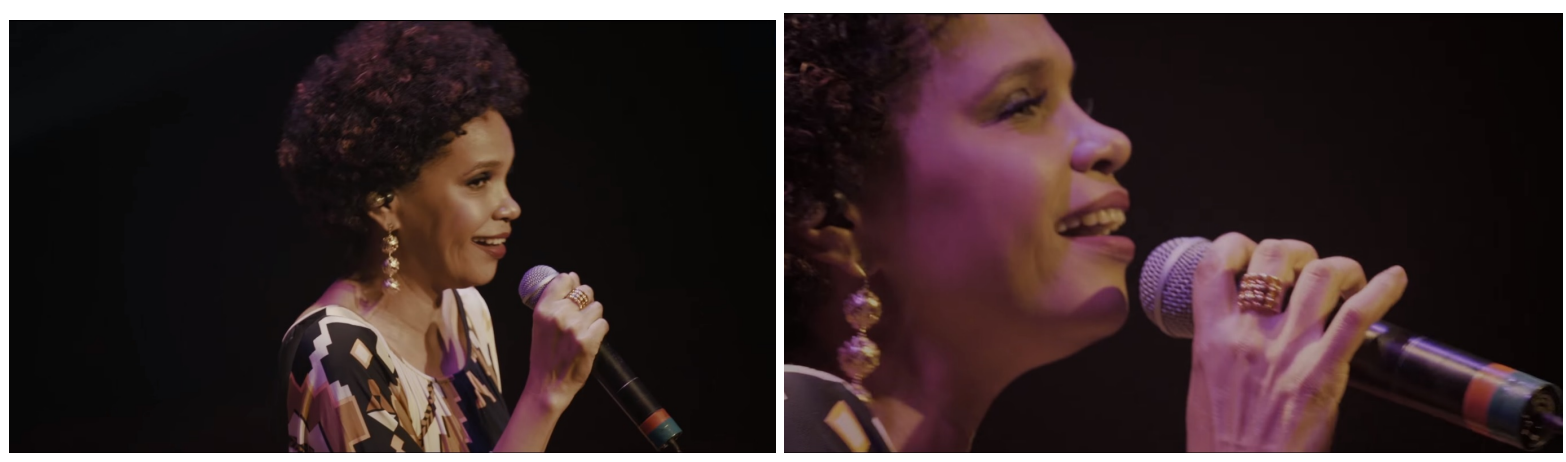

Frames 5 e 6. Fonte: YouTube.

Na segunda execução da letra, além do leve riso na voz, vemos que Teresa Cristina revira os olhos e encena um gesto de afastamento ao cantar "E vou calar" (frames 7 e 8). 0 gesto irônico de revirar os olhos é repetido em "Aiai, aiai" (frame 9) e ao final do canto, seguido de uma expressão pensativa, enquanto Carlinhos Sete Cordas conclui a música (frames 10 e 11).
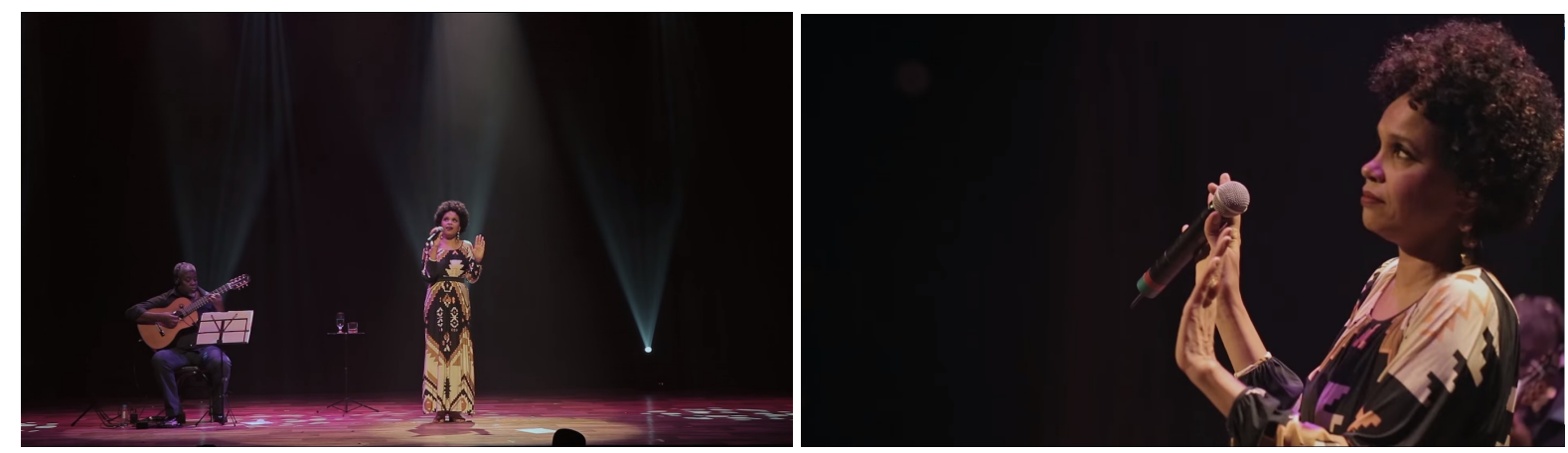

Frames 7 e 8. Fonte: YouTube.

Dossiê A Música e suas Determinações Materiais - https://revistaecopos.eco.ufrj.br/ 


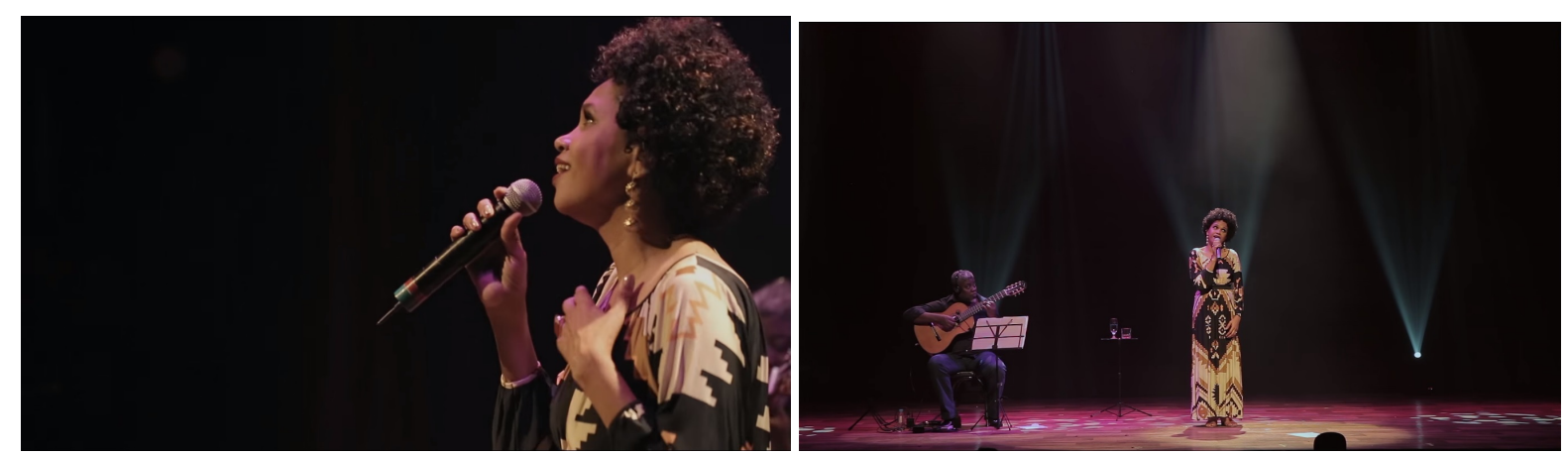

Frames 9 e 10. Fonte: YouTube.

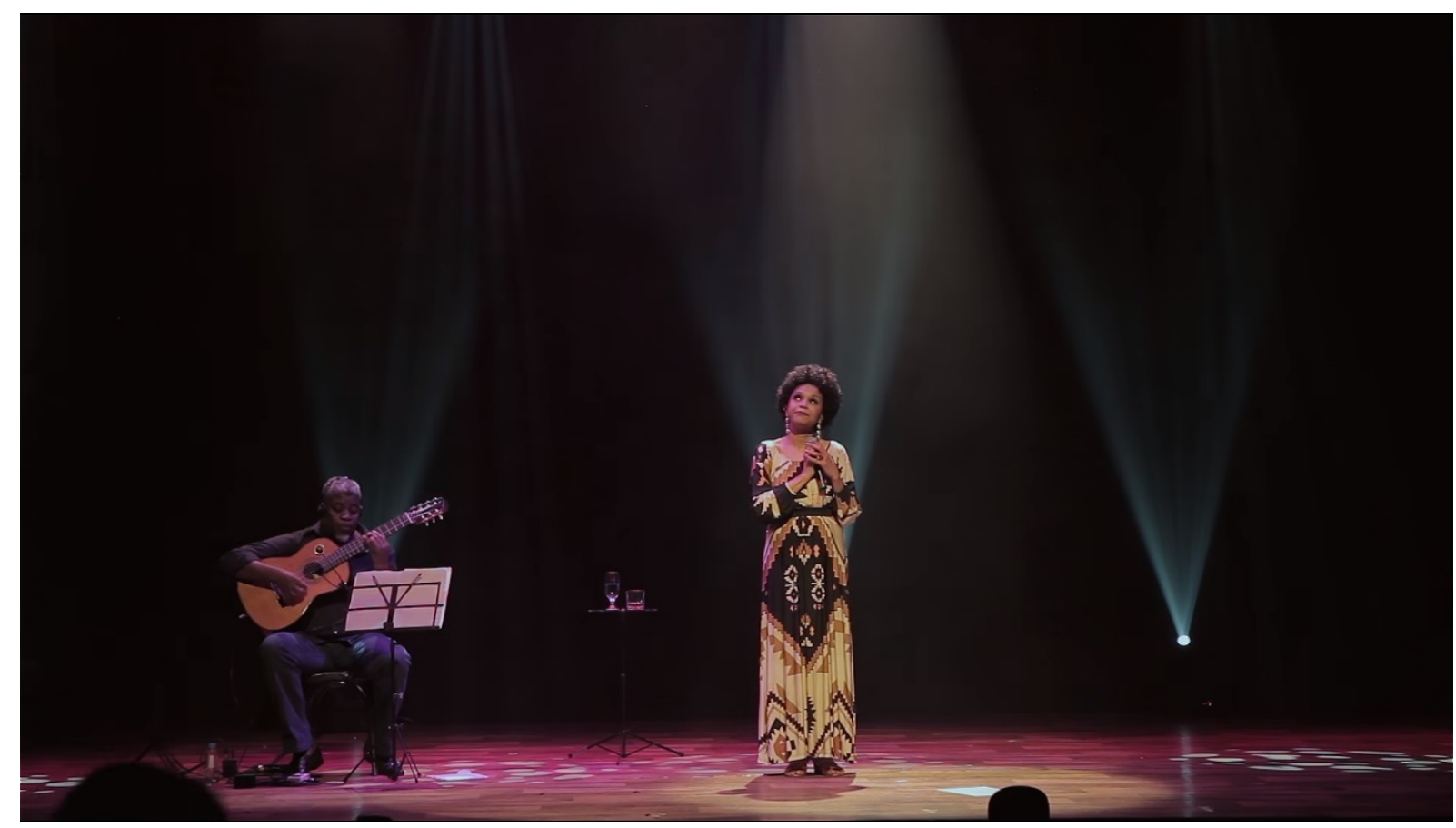

Frame 11. Fonte: YouTube.

Terminada a canção, Teresa Cristina verbaliza o desconforto e a reflexão já presentes, audíveis e visíveis em sua performance: "Essa música é de uma crueldade (...) é tão delicada, assim, ele vai falando, é cruel demais, gente. Meu Deus do céu. Imagina se fosse uma mulher falando isso para um homem. Imagina só". Esse convite à reflexão remete à desigualdade nas expectativas de comportamento para homens e mulheres nos relacionamentos, denunciando a assimetria de gênero que permeia a situação interacional da canção.

A troca nas posições de gênero, que, nessa versão, Teresa Cristina convida seus ouvintes a imaginar, passa a ser encenada a partir de certo ponto - constituindo o que 
chamamos de segundo momento, em que ela modifica sua estratégia de performance. Segundo afirma na entrevista ao El País, citada acima, seu incômodo com tal crueldade motivou-a a "brincar" com a canção, invertendo a flexão de gênero como forma de devolver o insulto ao lado masculino da relação:

Ele fala que tinha outra antes dela, que era muito feliz. E aí eu troco o gênero. Eu canto a música na voz masculina e depois faço na voz feminina. Como se a mulher virasse pro homem com a mesma postura que ele teve. É um momento muito legal do show. As mulheres se levantam, gritam e cantam junto (grifo nosso).

A inversão de gênero do eu-lírico em canções de amor não é um recurso incomum; no entanto, tende a ser mobilizado para resguardar o caráter heteronormativo da performance quando o(a) cantor(a) pertence ao gênero oposto do(a) compositor(a). Não é esse o caso de Teresa Cristina, já que ela não faz essa substituição na música inteira, mas canta as duas vozes ao longo da canção. A cantora destaca, aliás, que não costuma usar esse recurso e que a exceção se deve à solidariedade feminina: "Eu não gosto de trocar gênero de música. Eu respeito o compositor. Mas eu passei a sentir empatia por aquela mulher. Pô, uma mulher ouvir aquilo...”.

É possível apontar que a insensibilidade e crueldade no relacionamento afetivosexual retratado na canção provocaram uma ruptura em seu processo de identificação, movendo a cantora de seu posicionamento tradicional - situada apenas no lugar do eulírico que canta - para se reconhecer, também, do lado de quem hipoteticamente ouve aquelas palavras no relacionamento. Nesse sentido, a reflexão a partir do lugar de ouvinte da música a permitiu alçar outra dimensão, como ouvinte da crueldade do eulírico na situação interacional encenada. Sua estratégia possibilitou conciliar esse conflito com a canção:

E no final ele ainda fala: "Mas vou calar, pois não pretendo, amor, te magoar". E magoou a música inteira. Eu entendo que essa canção é dos anos 70. A relação do homem com a mulher era diferente. A mulher aceitava algumas coisas que a gente já não aceita mais. A música é linda. Mas desse jeito, fazendo a adaptação, fica mais natural para mim. Eu canto sem me sentir culpada de repetir esse discurso machista. 
A partir do reconhecimento nos dois lugares da relação encenada na canção, a inversão do gênero permite inscrever a mulher como sujeito na interação, dotada do poder de falar/cantar, nomear e até mesmo retribuir a decepção com o relacionamento atual em comparação com o anterior. A intérprete materializou, em sua performance, esse processo reflexivo de duplicidade das posições de cantora (eu-lírico, quem diz, quem define a situação, quem narra a canção) e ouvinte (ouvinte da canção, que se opõe a essa forma de se relacionar; e ouvinte no papel da companheira, que escuta e sofre a insensibilidade do eu-lírico).

$\mathrm{Na}$ primeira versão aqui discutida, as expressões corporais, vocais e faciais oscilam em relação à letra: em determinados momentos, a corroboram, enquanto em outros, parecem contradizer e ironizar as falas, corporificando o incômodo com o sexismo presente nelas. Já nas versões seguintes, que compreendem o que chamamos de segundo momento, a cantora passou a verbalizar seu posicionamento variável, cambiante, entre os lugares de homem/eu-lírico e mulher/ouvinte por meio da troca de gênero, habitando esses dois lugares ao longo da performance. Assim, nesse segundo momento de "Tive Sim", Teresa Cristina se ancorou nas versões de Cartola como referência, mas também em suas próprias versões anteriores, encadeando novas atualizações e inserindo a presença feminina no lugar de sujeito.

Nesse sentido, suas práticas de escuta opositora irromperam em reflexões e transformações que impactaram não apenas suas performances e a seleção de repertório, mas ecoaram, mais amplamente, em sua atuação no contexto do samba. Nas próprias palavras de Teresa Cristina:

A minha contribuição é tentar compor cada dia melhor e fazer sambas na voz feminina que tenham a mesma repercussão que as letras machistas tiveram. Apesar de discordar das mensagens que passam, reconheço que são músicas bem feitas, com uma amarração de versos e melodias belíssimas. Mas é preciso dar um contrapeso feminino à história do samba. ${ }^{22}$

22 “Teresa Cristina: 'O samba reflete o machismo, mas de um modo menos hipócrita'”. El País, 25 abr. 2017. Disponível em bit.ly/2tXSsXN. Acesso em 31 jan. 2020.

Dossiê A Música e suas Determinações Materiais - https://revistaecopos.eco.ufri.br/

ISSN 2175-8689-v. 23, n. 1, 2020

DOI: 10.29146/eco-pos.v23i1.27477 


\section{Considerações finais}

Ao longo deste artigo, abordamos as versões musicais em seu potencial de intervenção e transformação crítica nos vínculos metatextuais com suas versões de referência. Localizando esses gestos no terreno dos marcadores de gênero, raça e sexualidade, dentre outros, partimos do conceito de olhar opositor, de bell hooks (2019), e das posições hipotéticas de leitura, de Stuart Hall (2003), para refletir sobre práticas de escuta opositora. Discutimos como essas práticas reverberam em estratégias de resistência, com exemplos de contestação a canções, reconfiguração das seleções de repertório, tomada da voz em composições próprias e produção de versões atualizadas que transformam as canções de base. Com esse mapeamento de intervenções críticas a partir da escuta opositora no campo empírico, pudemos aproximar esse conceito da materialidade cotidiana de musicistas, diferenciando métodos e evidenciando a potência da ação das(os) intérpretes para a reconstrução de valores culturais.

Fundamentadas por esse percurso, discutimos as estratégias operadas por Teresa Cristina para lidar criticamente com letras ofensivas de compositores consagrados do samba. A cantora combinou táticas distintas: no caso de Noel Rosa, manteve fora do repertório canções com valores sexistas e racistas, operando com um código de oposição, preferindo cantar suas visões mais progressistas, com as quais reiterou a leitura preferencial por meio da reprodução em forma de homenagem. Fica evidente a dimensão do compositor como multifacetado e contraditório no conjunto de sua própria obra, a partir da qual o trabalho de seleção da intérprete diferencia os valores que ela acredita que devem ser enaltecidos daqueles que destoam de suas visões.

Da mesma forma, no canto a Cartola, determinadas canções não entraram para o setlist - que incluiu "Tive Sim", com as ressalvas da escuta opositora emergindo de forma central nas versões (re)atualizadas. Embora faça parte do mesmo sistema sexista, consideramos que, na comparação com manifestações mais violentas, essa canção apresenta uma forma de sexismo relativamente mais branda, o que permitiu sua 
apresentação com emendas ao invés de sua remoção do repertório. A cantora operou, assim, com um código negociado, inserindo suas próprias regras e valores na construção de contrapontos às lógicas de poder presentes nesse texto musical.

Nesse sentido, o conjunto de estratégias de Teresa Cristina constrói um diálogo potente, na medida em que não propõe aniquilar os compositores ou sua obra completa, mas homenageá-los com ressalvas; com sugestões sutis e afirmações contundentes de que o sexismo é inaceitável. Demarca-se um limite que exclui determinadas canções do repertório e operacionaliza outras para expor e se opor ao sexismo ali presente - por meio da escuta opositora materializada em sua voz, rosto, corporeidade e inversão na flexão de gênero na versão atualizada.

Em seu manifesto sobre a educação de crianças feministas, a escritora nigeriana Chimamanda N. Adichie (2017) afirma que o senso de identidade deve ser construído por meio da reflexão crítica sobre a própria cultura - diferenciando aspectos negativos, que devem ser interrogados e transformados, dos positivos, a serem preservados e apreciados. Na cultura igbo, citada pela autora, a importância da comunidade, do consenso e da dedicação ao trabalho estão entre os elementos que devem ser valorizados, transmitidos e ensinados às próximas gerações; enquanto a opressão das mulheres e o materialismo constituem o oposto.

Da mesma forma, é preciso uma apreciação crítica em relação a nossas tradições musicais e, mais amplamente, culturais e políticas. 0 samba é uma das riquezas da cultura diaspórica afro-brasileira, e devemos celebrar a importância de seus criadores. Mas as tradições culturais, mesmo quando ligadas a movimentos de resistência, não devem ser tomadas como fixas, tampouco como intocáveis. 0 reconhecimento desses compositores como pilares da história do samba não os posiciona acima de crítica e não os exime de responsabilidade pelo sexismo e/ou racismo que reproduzem em suas canções - ao contrário, a importância de suas obras só enfatiza a necessidade de debater os valores e violências simbólicas ali presentes, elaborando formas de intervir e modificar os termos de sua continuidade na história da música brasileira.

A partir das contribuições de Hall (2003) sobre as posicionalidades cambiantes operadas pelas audiências nas diferentes formas de leitura, pudemos refletir sobre as

Dossiê A Música e suas Determinações Materiais - $\underline{\text { https://revistaecopos.eco.ufri.br/ }}$ 
possibilidades de ação em relação aos sentidos preferenciais construídos nas versões de base: na composição de seu repertório de homenagem aos grandes sambistas, Teresa Cristina ocupou, em momentos distintos, as três posições de leitura apontadas pelo autor, demarcando seu posicionamento político diante das lógicas de poder presentes nos textos musicais.

Por meio das estratégias de atualização operadas pela cantora em suas versões, pôde emergir a potência teórica do gesto opositor descrito por hooks (2019), ao abrir a abordagem crítica para a reflexão não apenas sobre a particularidade desses textos musicais específicos, mas também sobre as posições tradicionais de sujeito e objeto fundamentando, assim, as estratégias de intervenção, transformação e subversão dessas posições nas práticas dos sujeitos nas dinâmicas de criação cultural e, mais amplamente, em suas interações nos demais âmbitos da vida social.

\section{Referências bibliográficas}

ADICHIE, Chimamanda N. Para educar crianças feministas: um manifesto. São Paulo: Companhia das Letras, 2017.

BAILEY, Moya; TRUDY. On Misogynoir: Citation, Erasure, and Plagiarism. Feminist Media Studies, v. 18, n. 4, p. 762-768, 2018.

CRENSHAW, Kimberlé. Mapping the margins: Intersectionality, identity politics, and violence against women of color. Stanford Law Review, v. 43, n. 6, p. 1241-1299, 1991.

HALL, Stuart. “Codificação/Decodificação”. In: SOVIK, Liv (Org.). Da diáspora: identidades e mediações culturais. Belo Horizonte: Editora UFMG, 2003. p. 387-404.

HOOKS, bell. "O olhar opositor: mulheres negras espectadoras". In: HOOKS, bell. Olhares negros: raça e representação. São Paulo: Editora Elefante, 2019. p. 214-241.

LÓPEZ CANO, Rubén. Lo original de la versión: de la ontología a la pragmática de la versión en la música popular urbana. Revista Consensus, v. 16, n. 1, p. 57-82, 2011.

TAYLOR, Diana. Performance. Buenos Aires: Asunto Impreso Ediciones, 2012.

TIVE SIM. Faixa do CD/DVD “Teresa Cristina Canta Cartola”. Produção: Uns Produções e Filmes. Disponível em youtu.be/hYYCV2rXe9E. Acesso em 31 jan. 2020.

WILLIAM, Rodney. Apropriação cultural. São Paulo: Pólen, 2019.

Dossiê A Música e suas Determinações Materiais - https://revistaecopos.eco.ufri.br/

ISSN 2175-8689-v. 23, n. 1, 2020

DOI: 10.29146/eco-pos.v23i1.27477 